\title{
Evaluation Of The Attitudes Of Surgeons About Regional Anesthesia: A Survey Study [Corrigendum]
}

Yılmaz İnal F, Yılmaz Y, Daşkaya H, et al. Local Reg Anesth. 2019;12:89-95.

We have been advised by the authors that Haran Uysal's affiliation was incorrect on the manuscript when they submitted it and therefore this needs to be corrected on the published paper.

Ferda Yılmaz İnal, ${ }^{1}$ Yadigar Yılmaz, ${ }^{2}$ Hayrettin Daşkaya, ${ }^{3}$ Mehmet Toptaş, ${ }^{4}$ Hasan Koçoğlu, ${ }^{1}$ Harun Uysal, ${ }^{4}$ İbrahim Akkoç $^{4}$

${ }^{1}$ Faculty of Medicine, Department of Anesthesiology and Reanimation, Istanbul Medeniyet University, Istanbul, Turkey; ${ }^{2}$ Department of Anesthesiology and Reanimation, Sultan Abdulhamid Han Education and Research Hospital, Istanbul, Turkey; ${ }^{3}$ Faculty of Medicine, Department of Anesthesiology and Reanimation, Bezmialem Vakıf University, Istanbul, Turkey; ${ }^{4}$ Department of Anesthesiology and Reanimation, Haseki Education and Research Hospital, Istanbul, Turkey

Should instead read:

Ferda Yılmaz İnal, ${ }^{1}$ Yadigar Yılmaz, ${ }^{2}$ Hayrettin Daşkaya, ${ }^{3}$ Mehmet Toptaş, ${ }^{4}$ Hasan Koçoğlu, ${ }^{1}$ Harun Uysal, ${ }^{3}$ İbrahim Akkoç$^{4}$

${ }^{1}$ Faculty of Medicine, Department of Anesthesiology and Reanimation, Istanbul Medeniyet University, Istanbul, Turkey; ${ }^{2}$ Department of Anesthesiology and Reanimation, Sultan Abdulhamid Han Education and Research Hospital, Istanbul, Turkey; ${ }^{3}$ Faculty of Medicine, Department of Anesthesiology and Reanimation, Bezmialem Vakıf University, Istanbul, Turkey; ${ }^{4}$ Department of Anesthesiology and Reanimation, Haseki Education and Research Hospital, Istanbul, Turkey

\section{Publish your work in this journal}

Local and Regional Anesthesia is an international, peer-reviewed, open access journal publishing on the development, pharmacology, delivery and targeting and clinical use of local and regional anesthetics and analgesics. The journal welcomes submitted papers covering original research, basic science, clinical studies, reviews \& evaluations, guidelines, expert opinion and commentary, case reports and extended reports. The manuscript management system is completely online and includes a very quick and fair peer-review system, which is all easy to use. Visit http://www.dovepress.com/testimonials. php to read real quotes from published authors. 